\title{
DIE PASTORALE BENADERING VAN DIE ALKOHOLIS
}

\section{Wie is die alkoholis?}

Wie presies die alkoholis is, is glad nie duidelik as 'n mens met die eerste oogopslag kennis maak met die magdom definisies en beskouinge oor alkoholisme. Baie van die bittere strydpunte en talle misverstande kan tot hierdie verwarring teruggevoer word.

'n Praktiese definisie is dié van Howard J. Clinebell: „An alcoholic is anyone whose drinking interferes frequently or continuously with any of his important life adjustments and inter personal relationships" (Clinebell, 1956, 17).

Op voetspoor van die „Espert Committee on Mental Health Alcoholism Subcommittee" het dr. P. H. Esser alkoholisme omskryf as ,ieder gebruik van alcohol, dat het zgn. sociale drinken te boven gaat" (Esser, 1960, 16).

Hierdie breër begrip van alkoholisme hou vir die pastorale bediening beslis sekere voordele in. Die probleem van nadelige en oormatige drankgebruik kruis die pad van die pastor in baie gestaltes.

\subsection{Alkoholisme en sy soorte}

I.1.1. Die wêreldbekende dr. E. M. Jellinek het die volgende bruikbare beskrywing van alkoholisme gegee: ,any use of alcoholic beverages that cause damage to the individual or society or both" (Jellinek, 1968, 35). Met hierdie omskrywing as uitgangspunt het hy vyf belangrike soorte alkoholisme, onderling verwant en tog verskillend, omlyn. Hy gee toe dat daar nog meer soorte is, maar hy beskou die vyf soorte as die belangrikste. Ek gee slegs 'n skematiese indeling van die vyf soorte (Jellinek, 1968, 35-41 en Oates, 1966, 26-30):

\section{a) Die eerste soort alkoholisme noem hy die}

Alfa alkoholisme: (Die Alfa-alkoholis word dikwels in ons spraakgebruik getipeer as die simptomatiese drinker).

Afhanklikheid: Blote sielkundige afhanklikheid.

Drinkpatroon: Ongedissiplineerde misbruik van drank sonder dat hy kontrole oor sy drankgebruik verloor of in 'n toestand beland waar hy nie meer kan ophou met drink nie. Sy drinkpatroon toon egter duidelik aantoonbare afwykinge van die sosiale norme.

Oorsake: Verligting van liggaamlike pyn of emosionele versteuring. Skade: Skade kan op verskeie vlakke aangerig word soos bv. versteuring van interpersoonlike verhoudings, onvermoë om huislike begroting te laat klop, sporadiese afwesigheid van werk, wanvoeding en gevolglike siektes ens.

Beinvloeding van gedrag: Gedrag word nie soseer deur die drankmisbruik beïnvloed nie, as dat sy alkoholisme 'n openbaring van ' $\mathrm{n}$ ander probleem is nie. 
Onttrekkingsimptome: Geen.

Siektetoestand: Dit is nie 'n siekte op sigself nie. Dit is 'n simptoom van patalogiese toestande. Alfa-alkoholisme mag in gammaof delta-alkoholisme ontwikkel.

b) Die tweede soort noem Jellinek beta-alkoholisme. (Die Betaalkoholis word soms die gewoontedrinker genoem).

Afhanklikheid: Geen sielkundige of liggaamlike afhanklikheid van alkohol nie.

Drinkpatroon: Gereelde (oormatige) gebruik, sonder dat hy kontrole oor sy drankgebruik verloor of in ' $n$ toestand beland waar hy nie kan ophou met drink nie.

Oorsake: Oormatige drankgebruik is 'n gewoonte in die sosiale groep waarin hy beweeg. Swak eetgewoontes speel ook 'n aktiewe rol.

Skade: Alkoholiese komplikasies soos polineuropatie, maagaandoenings en verharding van die lewer kom voor a.g.v. die voedingsgebreke. Ander moontlike skade kan voorkom in die huislike finansies, verlaagde produktiwiteit, verkorte lewensverwagting ens.

Beïnvloeding van gedrag: Gedragsveranderings is nie so belangrik as die liggaamlike skade wat aangerig word nie.

Onttrekkingsimptome: Geen.

Siektetoestand: Beta-alkoholisme is geen siekte op sigself nie. Die voorkomende siektetoestande word deur voedingsgebreke veroorsaak. Beta-alkoholisme mag in gamma- of delta-alkoholisme ontwikkel.

c) Die derde soort word die gamma alkoholisme genoem.

Dit is die groep waarmee ons onder die blankes van ons land die meeste te doen kry. Veral onder invloed van Alkoholiste Anoniem en vanweë die verwoestende aard van die Gamma-alkoholisme, word hierdie groep gewoonlik as die ,eintlike" alkoholiste beskou. Die Gamma-alkoholisme is reeds intensief ontleed. Jellinek was ook grootliks verantwoordelik vir die vandag algemeen aanvaarde indeling van die verskillende fases in die soort t.w. die pre-alkoholiste fase, die inleidende (prodromale) fase, die kritieke fase (wat dikwels weer onderverdeel word in die vroeë en laat kritieke fases), en dan die kroniese fase (Jones, 1963, 8/9). Die meeste boeke oor alkoholisme spits hulle toe op hierdie soort.

Afhanklikheid: Sielkundige afhanklikheid ontwikkel tot liggaamlike afhanklikheid deurdat die selmetabolisme verander.

Drinkpatroon: Afhanklikheid van drank met verlies van kontrole. Die alkoholis slaag egter weer daarin om nugter te word.

Oorsake: Op talle oorsake op sielkundige, sosiologiese, sosio-ekonomiese, liggaamlike, godsdienstige en farmakologiese gebied is reeds gewys. Gamma-alkoholisme kom gewoonlik voor waar drank met 'n hoë alkoholpersentasie gebruik word.

Skade: Daar vind ingrypende, nadelige gedragsveranderings plaas. Interpersoonlike verhoudings word geruïneer. Finansiële moei- 
likhede duik op. Produktiwiteit neem af. Die alkoholis vereensaam. Die gesondheid word benadeel, ens.

Beinvloeding van gedrag: Ingrypende gedragsveranderings vind plaas.

Angstoestande, skuldkompleks ens. speel 'n groot rol.

Onttrekkingsimptome: Besliste onttrekkingsimptome en sug na drank. Siektetoestand: Die soort alkoholisme word as siekte beskou.

d) Die vierde soort alkoholisme word die Delta-alkoholisme genoem.

Die soort is baie soortgelyk aan Gamma-alkoholisme, maar die skade is nie so ingrypend nie. I.p.v. kontroleverlies, is die onvermoë om sonder drank klaar te kom, 'n kenmerkende eienskap. Die hoeveelheid drank wat gedrink word, kan beheer word.

Afhanklikheid: Die sielkundige behoefte na drank of die sosiale gewoonte lei tot liggaamlike verslawing.

Drinkpatroon: Onafgebroke afhanklikheid van drank en die onvermoë om sonder drank klaar te kom, en beheer oor die kwantitatiewe inname van drank, is van die belangrikste kenmerke van die soort alkoholis se drinkpatroon.

Oorsake: Die oorsake is in hoofsaak soortgelyk aan die van Gammaalkoholisme, met die verskil dat dit hoofsaaklik voorkom waar drank met 'n lae alkoholpersentasie gebruik word.

Skade: Aangesien die Delta-alkoholis nie deur die ellendige sosiale en sielkundige verknorsings gaan nie, is die skade nie naastenby so intensief as by die Gamma-alkoholis nie. Gesondheidsprobleme en verkorting van die lewe is die belangrikste skade.

Beïnvloeding van gedrag: Slegs beperkte gedragsveranderings kom voor.

Onttrekkingsimptome: Besliste onttrekkingsimptome en sug na drank kom voor.

Siektetoestand: Die soort alkoholisme word as siekte beskou.

e) Die laaste soort alkoholisme is die Epsilon-alkoholisme.

Hulle word gewoonlik die kwartaaldrinkers of periodieke drinkers of dipsomane genoem (Esser, 1960, 37). Dit is die soort alkoholisme waarvan die minste bekend is. Sommige Gamma-alkoholiste neem na hul ,herstel" die drinkpatroon van die Epsilon-alkoholis aan, deurdat hulle sporadies losbreek en dan weer berouvol terugkeer na nugterheid. Jellinek noem hulle die ,pseudoperiodic alcoholics".

Afhanklikheid: Die sielkundige sug is primêr.

Drinkpatroon: Dié alkoholis breek sporadies los. Van dié alkoholis is nog min wetenskaplik bekend.

In punte II en III sal ek hoofsaaklik op die gamma-alkoholis konsentreer. Ek glo as die pastor die gamma-alkoholis doeltreffend kan benader en bearbei, hy die ander soorte ook wel sal kan help. Dit moet ook beklemtoon word dat die alkoholis nie so gemaklik in die afsonderlike kompartemente ingedruk kan word nie. Dit blyk uit die feit dat die een tipe alkoholis in die ander soort kan oorgaan. 
1.1.2. Daar is ook ander eenvoudige, enger indelings wat ook vir die pastor ' $n$ mate van orde kan bring in die oerwoud van alkoholisme. John Doe, die Katolieke priester, beperk alkoholisme tot dwangmatige drankgebruik (complete obsession or compulsion of the mind leading to excessive consumption - Doe, 1965, 9). Hy het sy indeling soos volg geformuleer (Doe, 1965, 13):

a) Die neurotiese alkoholis ( $80 \%$ van die Amerikaanse alkoholiste). Die alkoholis het 'n definitiewe neurose as deel van sy alkoholistetoestand. Hy is neuroties voordat hy begin drink of word neuroties deur die oormatige drankgebruik.

b) Die gewone verslaafdes (15\% van die Amerikaanse alkoholiste). Die persoon het skynbaar geen neurose nie, maar kan tog nie sy drankgebruik beheer nie, hoe hard hy ook al probeer.

c) Die psigopaat. (Vyf persent van die Amerikaanse alkoholiste val in die kategorie). Die psigopaat is sielsiek en drink as gevolg daarvan.

1.1.3. Ruth Fox het ook met die oog op die oorsake van alkoholisme, 'n indeling gegee (Kruger, 1966, 9).

a) Die sekondêre alkoholis: Die persoon het geen besondere sielkundige behoefte aan alkohol nie, maar drink tog al hewiger en hewiger, totdat hulle afhanklik raak van alkohol en die karaktertrekke van 'n drankverslaafde begin openbaar.

b) Die primêre alkoholis: Dit is die persoon wat gewoonlik op emosionele vlak wanaangepas is. Hy is onderhewig aan gevoelens van onsekerheid. Die eerste drankie bied vir dié persoon groot verligting en emosionele bevryding. Alkoholisme is ' $n$ simptoom van dieperliggende persoonlikheidsgebreke.

c) Die omstandigheidsalkoholis: Alkoholisme ontstaan hier by 'n normale persoon wat onder buitengewone emosionele spanning geplaas word en nie in staat is om hierdie spannings op 'n normale wyse te verwerk nie.

Dit is genoeg om aan te toon dat die pastor by elke alkoholis moet soek na sy eiesoortige omstandighede wat 'n rol speel in sy probleem. Die indelings toon ook aan ons dat nie slegs die pastor en die kerk 'n taak teenoor die alkoholis het nie. Sonder om vir een oomblik die belangrikheid van die pastorale bediening teenoor die alkoholis te probeer kleineer, lewer die blote godsdienstige benadering baie ontnugterende teëslae op. Die alkoholis het dikwels ook mediese en/of psigiatriese behandeling nodig.

\section{I.2.1. Die etiese vraagstuk van alkoholisme.}

Vir baie pastores is dit ' $n$ brandende vraagstuk. Is alkoholisme sonde? Vir my is dit bo alle twyfel sonde. Maar dan wil ek in dieselfde asem pleit dat ons moet wegkom van die so populêre en oppervlakkige opvatting dat net wat ' $n$ mens moedswillig doen, eintlik 
sonde is. Ek kan die woord sonde maklik soos 'n etiket gebruik om iemand aan te dui wat nie in dieselfde klas as ek val nie. Sonde is iets veel diepers; ingrypenders en tragies: lees 'n slag Rom. 7! Dan sal $u$ besef dat sonde soos die klewerige spinnekopweb in die lewe van elke mens is. Ook in die lewe van die pastor.

Sonde is volgens die Heilige Skrif oortreding van die goddelike wet - of dit nou bewus of onbewus geskied. Die Hebreeuse woord hatta't word die meeste in die Ou Testament gebruik om sonde aan te dui, en beteken letterlik: om die doel te mis, om nie te bereik wat 'n mens moes bereik nie. Die nadruk van hierdie woord lê op die kwade eind resultaat van die menslike handeling en nie op die verborge innerlike bedoeling nie (Pop, 1957, 258). Die norm bly God se wet. As ons handelswyse nie die doel tref nie, dan is dit sonde. Twee ander woorde wat in die Bybel gebruik word, lê klem op die afwykende aard van die daad of lewenswyse. Die woord is die $\mathrm{He}$ breeuse woord a wōn en die Griekse woord a dikia. Dié woorde in die Bybel toon dus aan dat sonde 'n afwyking van die regte lyn, insetting en wet is (Honig, 1938, 392). Die apostel Johannes sê: „Elkeen wat die sonde doen, doen ook die wetteloosheid, want die sonde is wetteloosheid" ( 1 Joh. $3: 4$ ).

In hierdie sonde speel die persoonlike verantwoordelikheid van die alkoholis wel in ' $n$ mindere of meerdere mate 'n rol. Hoeveel kan werklik nie duidelik bepaal word nie, omdat daar so ontsettend baie faktore is wat 'n rol speel. Dit is seker ook nie nodig om die verantwoordelikheidsgraad vas te stel nie: solank ons hom maar net leer om sy verantwoordelikheid na die beste van sy vermoë te aanvaar.

By die daadwerklike sonde, is daar nog die aangebore of erfsonde (vgl. Rom. 3 en Rom. 5 : 12-21). Bavinck stel dit mooi: „De eerste zonde, waaraan de stamouders van het menschelijk geslacht zich hebben schuldig gemaakt, heeft voor hen zelf en voor al hunne nakomelingen zeer schrikkelijke gevolgen gehad en een stroom van ellende oor de menschheid uitgestort. Het menschelijke geslacht in zijn geheel en ieder lid ervan in het bijzonder is daardoor met schuld beladen, door onreinheid bevlekt, aan verderf en dood onderworpen" (Bavinck, 1929, 54).

Dat alkoholisme nie sonde is nie (en daarmee word gewoonlik bedoel: nie blote moedswilligheid is nie) word gewoonlik deur die lede van Alkoholiste Anoniem voorgestaan. Maar in die lig van die Bybelse omskrywing van sonde erken ook die Alkoholiste Anoniem die sondekarakter van alkoholisme, sonder om dit direk so te noem. In die herstelprogram lui die eerste stap: „Ons het erken dat ons magteloos was teenoor alkohol, en dat ons lewe onbeheerbaar geword het". Hulle erken dus dat hulle lewe die doel gemis het. Stap 8 lui so: „Ons het 'n lys opgestel van al die persone wat deur ons benadeel is, en ons het ons bereid getoon om hulle daarvoor te vergoed". Stap 9 lui: „Ons het regstreekse vergoeding gedoen aan sulke mense, waar dit ook al moontlik was, behalwe waar ons hulle of andere sou benadeel het deur dit te doen”. Stap 10 lees: „Ons 
het voortgegaan om 'n persoonlike inventaris op te stel, en waar ons verkeerd gehandel het, het ons dit erken (Alkoholiste Anoniem, 69).

Die miskenning dat alkoholisme ook 'n sondeaspek het, word gewoonlik gebruik om die verterende skuldgevoel en minderwaardigheidsgevoel by die alkoholis te verlig. Dit word ook gebruik om die alkoholis se verdedigingsmeganismes (en daar is baie!) te verswak. Maar ons het ook as predikante skuld daaraan, aangesien die aanvaarding van die sondeaspek vir ons dikwels blote moedswilligheid insluit. Die opvatting word dan weer dikwels gebruik vir die motivering van pastorale onbegrip en ontwyking. Die houding: „Hy het self in die gemors beland, hy moet maar sien en kom klaar", is nie verantwoord nie. Verder moet ons kennis neem van die breër liggende faktore wat ' $n$ rol speel in alkoholisme.

Die aanvaarding van die sondekarakter van alkoholisme, het veral drie gevolge:

I.2.2. Eerstens, dat die alkoholis ' $n$ persoon is wat behoefte het aan die genade van Jesus Christus. Dit laat 'n mens dink aan die baie tekste in die Skrif waar die besondere liefde van Christus teenoor die sondaar, onderstreep word. "Want die Seun van die mens het gekom om te soek en te red wat verlore was" (Luk. $19: 10$ ). Omdat die leraar ' $n$ dienskneg van Christus is, mag hy hom onder geen omstandighede van die alkoholis distansieer, omdat die alkoholis 'n "sondaar" is nie. Die pastorale taak word mooi in Ef. 4 : 11 tot 16 omskryf: „En Hy het gegee sommige as apostels, ander as profete, ander as evangeliste, ander as herders en leraars, om die heiliges toe te rus vir hul dienswerk, tot opbouing van die liggaam van Christus, totdat ons almal kom tot die eenheid van die geloof en van die kennis van die Seun van God, tot 'n volwasse man, tot die mate van die volle grootte van Christus: sodat ons nie meer kinders sou wees nie wat soos golwe geslinger en heen en weer gedryf word deur elke wind van lering, deur die bedrieëry van die mense, deur sluheid om listiglik tot dwaling te bring: maar, terwyl ons in liefde die waarheid betrag, in alles sou opgroei in Hom wat die Hoof is, naamlik Christus, uit wie die hele liggaam - goed saamgevoeg en saamverbind deur die ondersteuning wat elke lid gee volgens die werking van elke afsonderlike deel in sy mate die groei van die liggaam bevorder vir sy eie opbouing in liefde". Paulus noem dit in 2 Kor. 5:17-19 die ,bediening van die versoening".

Hoe belangrik die rol van die pastor is, word mooi weergegee deur die Amerikaanse skrywer John G. McKenzie: „... although psychology can discover the unconscious elements in man which cause his predicament and estrangement, it cannot of itself get him out of his predicament, nor end his estrangement. It cannot give him meaning nor can it give him the meaning to life he needs to relate him to moral order...

We are thrown back on religion, it alone has proved also its power to make guilt the first step to wholeness by showing that it 
is an anxious longing for God from Whom we are estrange. It is religion that prevents guilt from being the first step in repression that leads to pathological illness" (McKenzie, 1962, 163).

1.2.3. Tweedens, is dit duidelik dat die alkoholis behoefte aan die versoeningsgenade van Christus het, dan moet die pastor met al die takt en liefde die struikelblokke verwyder, sodat die bediening van die versoening doeltreffend kan wees. Nie alleen die eie geduld en lankmoedigheid, moet beklemtoon word nie, maar dit is heel dikwels nodig om psigiatriese en mediese behandeling vir die alkoholis te kry, alvorens met die bearbeiding voortgegaan word. Die oorhaastige, ongeduldige en ontaktvolle benadering slaag nooit. Christus het die verlore skaap gaan soek en op sy skouers teruggedra (Luk. $15: 4,5$ ). Dit is die herdersbeeld van die Skrif.

1.2.4. 'n Derde aspek is dat die pastor die alkoholis as medesondaar moet benader. As gevolg van die vereensaming het veral die gamma-alkoholis uiters gevoelig geword vir enige veroordeling of antipatie. Keller sê: "It is right here that the nature of the fellowship of the church as a loving understanding, accepting, responsible fellowship is of vital importance. In this fellowship, established by Christ himself, there is to be an awareness of our own common sinfulness, weaknesses, problems and responsibility. Here there is to be a "feeling" communication that gets through to the person - a communication of understanding and acceptance of one another in our estrangement. Within this fellowship people are to feel free to be essentially as they are. They don't have to be pretenders" (Keller, 1966, 14).

\section{Bearbeidingsfases}

Vervolgens wil ek $u$ aandag oorsigtelik bepaal by die algemene bearbeidingsfases.

\section{II.1.1. Vertrouensband met die alkoholis}

Waar die alkoholis in die skadus van verbrokkeling leef sal die natuurlikste reaksie die reaksie van vyandigheid en terugtrekking (vereensaming) wees (Klink, 1965, 103). As gevolg van die vereensamingsproses moet ' $n$ brug oor die bestaande klowe gebou word. Dit is noodsaaklik dat die pastor met die regte gesindheid tot die alkoholis moet kom.

Dit is ook noodsaaklik dat die pastor die alkoholis moet begryp. Keller stel dit mooi: „Stay close to his Ego" (Keller, 1966, 71); laat die alkoholis op indirekte wyse voel en hoor dat hy verstaan en aanvaar word. Selfs later as die gesprek reeds vlot, is dit noodsaaklik om die alkoholis met volle begrip te benader, en bewus te probeer bly van wat vir hom belangrik is en wat nie. „As die predikant geen aanvoeling vir situasies, emosies, probleme, grense, nood, verleentheid, dilemma, versoeking ens., het nie, ervaar die lidmaat hom as stug, geslote en onsimpatiek. Dit gee aan die lidmaat die gevoel van onveiligheid by die pastor, 'n gevoel dat hy nie begryp 
word nie - en daarom, ontsluit hy nooit en vind geen werklike ontmoeting plaas nie. Daarteenoor is 'n begripvolle, aanvaardende, gemeenskaplike, humane, bewoë en simpatieke persoonlikheid dié groot stimulans vir pastorale ontplooiing" (De Klerk, 1965, 1). Die invoeling (empatiese identifikasie) is by die alkoholis onontbeerlik. Die alkoholis het 'n krimpvarkie-geaardheid - sodra hy die grond voel dreun, maak hy ongenaakbaar toe, sy penne vyandig na buite gerig. Deur die voortdurende aanvaarding word 'n vertrouensband opgebou.

Dit is ook noodsaaklik om aan die alkoholis die geleentheid te gee om die hele situasie te deurvors en vertroue te wen. Waar die alkoholis uit sy eie om hulp kom vra, kan ons aanvaar dat die mate van vertroue reeds daar is sodat 'n vertrouensband reeds bestaan. Dit moet dan net verder uitgebou word. Maar waar die inisiatief tot kontak van die pastor se kant kom, moet uiters versigtig te werk gegaan word. Die kuiertjies en die geselsies oor koeitjies en kalfies is nie tydmors nie. Die noodsaaklike en onontbeerlike fondament vir die latere bearbeiding moet geduldig en dikwels langsaam gelê word.

Persoonlik glo ek aan besoeke as die alkoholis gedrink is, of as hy siek is. Die blote feit dat hy in sulke „ontblote" omstandighede aanvaar word, en nie veroordeel of vermaan word nie, laat dit langsamerhand tot hom deurdring dat hy aanvaar word.

In die stadium moet hy minstens een keer per week besoek word. Besoeke te lank uit mekaar gespasieer, bring niks tot stand nie.

II.1.2. Dit moet ook hier aangestip word dat die samewerking en die vertroue van die familie ook in hierdie stadium verkry moet word. Ek het dit al dikwels ervaar dat die familie 'n gedugte vyand kan wees. Hulle kan die pastor gebruik om die alkoholis mee te dreig. Hulle kan hom verkeerd benader: soms is die benadering so antipatiek, dat dit die afbrekende emosies verskerp; dan weer is die benadering so simpatiek en beskermend dat dit die alkoholis in sy kwaad versterk. Hulle kan deur die onttrekking van hulleself en die uitskakeling van die alkoholis die verwoestende afbreekproses van vereensaming aanhelp. Die pastor sal baie moet moed inpraat, tot liefde aanspoor, tot beter insig bring, liefdevol moet vermaan en die vereensamingsproses wat die familie aanbetref moet teëwerk.

Die doelpunt van die eerste fase, is die daarstelling van die vertrouensband.

II.2. Die tweede fase wil ek die fase van selfontdekking noem.

By sommige alkoholiste is daar redelike begrip van hul probleem. 'n Paar ophelderende gesprekke kan hulle tot selfherkenning bring. Die persoon wat uit sy eie hulp kom soek, moet homself en die omvang van sy probleem dikwels nog self ontdek. By sommige alkoholiste lê hier egter 'n moeisame pad voor. Solank hy sy beproefde ontvlugtingsmeganismes gebruik en 'n beskermende omgewing het om hom te beskerm, is dit soms moeilik om die deurbraak te maak. 
II.2. Die selfontdekking kan aangehelp word deur die vertrouensband te verstewig. Insig in jouself kom stadig, stap vir stap, namate die individu ontwikkel om dit te dra (Rogers, 1942, 177). Daarom bly dit noodsaaklik om 'n goeie gespreksklimaat te skep, want daarin sal die alkoholis die gouste ontplooi (Clinebell, 1966, $140)$. Hierdie vertrouensband tussen alkoholis en predikant het self baie met die ontplooiing van die alkoholis te doen.

Selfontdekking kan verder aangehelp word deur 'n taktvolle deurdra van die benadeelde werklikheid. Die alkoholis is egosentries ingestel. Daarom moet liefs op sake gekonsentreer word wat homself raak. Hy moet op 'n mooi manier gewys word op die gevare wat dreig, asook op die onrealistiese verskonings en alibisisteme en selfhelpmetodes.

Die terugval-hulp moet ook sover moontlik verwyder word. Onoordeelkundige beskerming van die alkoholis lei dikwels tot 'n verdieping in die alkoholistiese lewenswyse. Iemand het dit so uitgedruk: "Moet die alkoholis nie abba nie". Clinebell noem dit raak ,withdrawing the props" (Clinebell, 1966, 196). Iemand wat die alkoholis soos 'n invalide help, help hom opnuut en in 'n versterkte mate aan drank (Esser, 1960, 159). 'n Simpatieke benadering is nodig, maar dan 'n benadering wat die probleem sal oopvlek. In die vertrouensklimaat wat geskep is, en met die verdiepte en meer realistiese insig in sy posisie, erken die alkoholis een of ander tyd dat hy magteloos is en hulp nodig het.

Wat die besoeke aanbetref: sodra die vertrouensband begin vorm aanneem, moet die besoeke begin toeneem. Al die besoeke hoef nie oor die probleem te handel nie. Ek glo dat die alkoholis meesal die inisiatief moet neem deur die probleem aan te sny. Die pastor kan dan die probleem in sy verbande rustig tuisbring. 'n Voortdurende konsentrasie op die probleem van pastorale kant, kan die alkoholis maklik bedreig laat voel, en gevolglik die ontplooiing tot selfontdekking belemmer.

\section{II.3. Die derde fase is die fase van verwysing}

Die alkoholis moet uitdruklik daarop gewys word dat hy hulp van buite nodig het (Clinebell, 1956, 177). Hy moet die verskillende moontlikhede van mediese hulp goed onder oë sien en verduidelik word wat hy daarvan kan verwag. Vandag, met die baie moontlikhede, is daar verskeie instansies wat die kliniese behandeling van die alkoholis behartig.

'n Baie geslaagde behandelingsmetode is die buite-kliniese metode, reeds toegepas o.a. deur die Johannesburgse vereniging van SANRA. Die voordeel van die buite-kliniese behandeling is dat die alkoholis behandeling kry terwyl hy voortgaan met sy gewone lewe. Ook kan die pastorale bediening gelyktydig deurgaan.

Dit is belangrik dat die pastor hom onder geen omstandighede van die alkoholis onttrek nie, al kry hy voltydse kliniese behandeling. As dit moontlik is, moet die pastor die alkoholis in die kliniek besoek. In geval van voltydse kliniese behandeling, moet die pastor so nou 
moontlik kontak met die alkoholis en sy gesin hou. Die tyd van werklike geestelike heropbou het nou aangebreek.

II.4. Die vierde fase is die fase van eintlike bearbeiding en geestelike heropbou.

Gesien van die kliniese kant, is dit nasorg. Van die kant van die kerk is dit die tydperk van werklike geestelike ontplooiing. Ek sal met die behandeling van die bearbeidingsvlakke onder punt III die omvang van die taak verder omlyn. In die tydperk kan en moet van verskeie metodes gebruik gemaak word.

\section{II.4.1. Die pastorale gesprek}

Genoeg tyd moet gevind word om met die alkoholis alleen te gesels. Hy het aanvanklik nog nie veel vriende nie. Hy het pas met die lê van die vertrouensband weer begin om sy lewe oop te stel. In die verhouding pastor-alkoholis sal hy in die begin dikwels voel dat die alkoholis geestelik swaar op hom leun. Alhoewel gewaak moet word teen oorafhanklikheid, moet die afhanklikheid aanvanklik tot 'n mate aanvaar word. Namate die alkoholis eie verantwoordelikheid kan aanvaar, moet hy sy eie probleme uitstryk, en op sy eie voete staan. Die posisie van die alkoholis moet in die verhouding gekenmerk word deur groei van onvolwassenheid na volwassenheid. Hy moet leer dat God hom liefhet, en verantwoordelikheid aan hom wil toevertrou. Die mens bly koning onder die genade van God.

\section{II.4.2. Die bearbeiding van die familie}

Daar moet ook genoeg tyd gevind word om die familie van die alkoholis gereeld te sien. Ingrypende rolsveranderinge moet nou plaasvind. Gesinslede moet leer om mekaar te aanvaar en harmonies met mekaar saam te leef. Donald E. Macdonald vertel van vroue wat psigoties geword het nadat hul mans opgehou het met drink. Veral die eerste tyd nadat die alkoholis opgehou het met drink, kan aardige spanningstoestande voorkom. Ook hier kan die godsdienstige verdieping baie beteken en die moeilike aanpassings vergemaklik. Ek verstom my dikwels hoe die riglyne van Gods Woord in spanningstoestande vreedsame rustigheid en werksaamheid kan bring.

\section{II.4.3. Aktivering van die alkoholis}

Aktivering van die alkoholis kan geweldig baie beteken. Dit is so dat die een alkoholis gewoonlik baie gou deur die kors van 'n ander alkoholis kan dring. So kan 'n alkoholis (en sy gesin) aan hom toevertrou word. Hy en sy vrou kan by een of ander aksie ingeskakel word. In die diens wat hulle lewer word nuwe vreugdes ontdek en lewensbehoeftes vervul. Diens lei tot vryheid (Gal. 5:13).

\section{II.4.4. Inskakeling by groep of gemeenskap}

Die groepsbelewing is eintlik 'n noodsaaklike voorwaarde vir die herstel van die alkoholis. Die groot mate van sukses wat met groeps- 
terapie buite die kerk behaal word, wys duidelik dat groepsbearbeiding binne die kerk van groot waarde kan wees. Reeds voor die selfontdekking kan die groepsatmosfeer gebruik word om die alkoholis tot selfontdekking te bring. In die groep is 'n menigte van kragte en prosesse aan die werk. Die hersosialisering van die alkoholis is van groot belang. Die groepsbelewing het 'n wonderlike stimulerende uitwerking op die geloofslewe. So 'n beskermende groep gee aan die alkoholis die geleentheid om homself te wees. Hy kry besondere vertroue om sy probleme te pak en kleingeld te maak. Die individuele probleme van die alkoholis berus in ' $n$ groot mate by die ontwrigte lewensverbande wat nie sy persoonlike behoeftes bevredig nie (Clinebell, 1966, p. 31). Dwarsdeur die lewe is die persoonlike geestelike gesondheid afhanklik van voldoende bevrediging van persoonlike behoeftes deur persoonlike verhoudings. Verbasend baie behoeftes word bevredig of gedeeltelik bevredig deur 'n konstruktiewe groepsbelewenis (Clinebell, 1965, 152). Buitendien is dit my vaste oortuiging dat daar in die Christelike gemeenskap iets opbouends en versterkends is (Clinebell, 1965, 153). Die kameraadskap op grond van gemeenskaplike ondervinding, is iets waarvan gebruik gemaak moet word. Om al die alkoholiste by so 'n groepsbearbeiding in te skakel, is natuurlik nie altyd so maklik nie.

'n Paar van die voordele van die groepsbearbeiding, kan genoem word:

a) In die groepservaring word die geloof in God - veral by die alkoholis - besonder gebou.

b) Afwykende gedrag word tot die minimum beperk. Die groepsnorme soos bv. jy mag nie drink nie, jy moet gereeld kerk toe gaan, jy moet jou naaste help, ens. verskaf die noodsaaklike waardesisteem waarvolgens die alkoholis sy lewe aanvanklik kan inrig.

c) Die groepslede bied aan die alkoholis nuwe identifikasiemoontlikhede.

d) In die gunstige, beskermende klimaat word ontplooiing tot geestelike volwassenheid versnel.

e) Verskeie behoeftes, soos die behoefte aan sekuriteit, die ontvang en gee van liefde, aanvaarding in die sin van aanvaar word en self aanvaar, sosiale omgang ens. word vervul.

f) Dit word 'n oefenskool om homself te wees en homself uit te lewe.

g) Vir die pastor het dit self baie waarde. Die individuele alkoholis aanvaar hom as „buitestaander" baie makliker as die groep hom aanvaar.

h) Die pastor kan ook in die groepsbespreking luister vir die aanduidings van probleme en die meer persoonlike sake later in die persoonlike gesprek aan die orde stel.

i) Veral in die groter gemeentes vorm die kleiner groep 'n maklike weg tot inskakeling by die groter gemeentes, waar die alkoholis nie so gou op sy gemak voel nie. 


\section{II.4.5. Voorbidding}

Die laaste wat ek hier wil noem, is voorbidding. Partykeer word begin met voorbidding nog voordat met die alkoholis kontak gemaak word. Maar ek noem dit hier omdat dit 'n belangrike bearbeidingsmetode is. Voorbidding is ingebed in die belydenis van die afhanklikheid van God. Dit impliseer baie:

a) Die onweerstaanbare werking van Gods Gees is op 'n onverstaanbare, bomenslike wyse verbonde aan die gebed.

b) Die biddende pastor sal sy noodsaaklike nederigheid nie maklik kan verruil vir skyngrootheid nie.

c) Dit bevrug en bring seën op die praktiese werk wat verrig word.

\section{Bearbeidingsvlakke}

Die pastorale bearbeiding het invloed op al die lewensverhoudings waarin die alkoholis staan, nl. die Ek-dit-verhoudings, die Ek-jy-verhoudings, die Ek-self-verhoudings en die Ek-God-verhoudings. Die herstel van die alkoholis, gesien van pastorale kant, berus op die aanpassing in die verskillende lewensverhoudings (Hoff, $1963,465)$. So 'n groep lewensverhoudings wil ek 'n verhoudingsvlak noem en die praktiese bediening in ' $n$ verhoudingsvlak, ' $n$ bearbeidingsvlak.

Die verhouding vorm 'n ingewikkelde netwerk, en oefen op dinamiese wyse invloed op mekaar uit. In die Bybel kry ons baie mooi voorbeelde: Die breuk tussen God en Adam (Ek-God-verhouding), lei tot versteuring in die Ek-self-verhouding, deurdat hy angs en onsekerheid ervaar. Hy probeer homself met 'n skort van vyeblare dek! Dit lei tot versteuring in die Ek-jy-verhouding, deurdat hy, wat sy vrou volmaak liefgehad het, haar nou verwyt. Dit lei tot versteuring in die Ek-dit-verhouding, deurdat die wêreld nou dorings en distels oplewer, en hy met moeite sal werk. Ek glo dat die sonde en die sondige toestand (die breuk met God) die diepste oorsaak van al die ellende is. Daarom is die verkondiging van die genade van Christus so belangrik. As ons met God gemeenskap het, (Ek-God-verhouding - 1 Joh. 1 : 6), dan word ons kinders van God (1 Joh. 3: 1 - watter invloed het dit nie op die Ek-self-verhouding nie!) en die nuwe skepsel word deur liefde teenoor sy naaste gekenmerk (1 Joh. $3: 11$. - Die Ek-jy-verhouding). Ook het die geloof in Christus daadwerklike gevolge in die Ek-dit-verhouding (Rom. 6:13,12:2). Bohne toon mooi aan dat verbondenheid aan God lei tot 'n nuwe bestaanswyse, 'n nuwe lewenswyse, 'n nuwe lewensbeskouing en 'n nuwe verhouding tot ander mense en die wêreld (Bohne, 1960, 44 v.).

Maar nie net die Ek-God-verhouding, as basiese verhouding, het invloed op die ander verhoudings nie. Vanuit elke verhoudingsvlak is daar kragte wat op die ander verhoudingsvlakke inwerk. So beinvloed die een verhouding die ander in dieselfde vlak en in ander vlakke, ten goede of ten kwade. 
Ek wil kortliks iets oor elke bearbeidingsvlak sê:

\section{III.1. Die ek-self-bearbeidingsulak}

Dat daar by die mens selfbewustheid bestaan, staan sielkundig vas. Selfbewussyn is die vermoë om jouself te aanskou en skeiding te maak tussen die ek en die self (Esser, 1960, 674), of die ek en die persoonlikheid (Kuypers, 1963, 261). Die selfgevoel of selfbeeld (De Willebois, 1965) of selfwaarde, is nie iets wat in 'n oomblik ontstaan het nie, maar ontwikkel oor baie jare.

III.1.1. Die rol wat die $\mathrm{Ek}$-self-verhouding in die lewe van enige mens speel, is enorm, en vir die geestesgesondheid van die allergrootste belang. Iemand wat nie bevredigende $\mathrm{Ek}$-self-verhoudings het nie, kan geen bevredigende aanpassings op ander vlakke maak nie. Die oorwegende lae selfwaarde by alkoholiste lei tot 'n ooreenstemmende gesindheid op baie ander terreine. Fey, wat die korrelasie tussen selfaanvaarding en die aanvaarding van ander bestudeer het, het 'n noue verband gevind. As die persoon homself nie kan aanvaar nie kan hy 'n ander ook nie aanvaar nie (Smith, 1961, 189 vgl. ook hier Manis, 1955, 362-376). Vervreemding van die self, word konsekwent gevolg deur vervreemding van die ander en die omliggende wêreld (De Willebois, 1965, 8). Sonder hierdie ontplooide bande en selfoorgawe, kan daar nie sprake van volwassenheid wees nie (Wijngaarden, 1963, 90).

III.1.2. Die oorsake van die Ek-self-versteurings kan tot 'n groot mate in die kinderjare en die huislike agtergrond gesoek word. In hul boekie „Originis of Alcoholism", het die McCord egpaar, miskien oordrewe maar op aangrypende wyse aangetoon watter verrykende gevolge 'n skewe opvoeding kan hê. Clinebell het in Amerika gevind dat slegs 10 uit elke 77 Amerikaanse alkoholiste nie 'n abnormale opvoedingsagtergrond het nie (Clinebell, 1956, 48). Taamlik algemeen is daar die letterlike en figuurlike afwesige of onbereikbare vader, wat onvoldoende geleentheid vir identifikasie gee (De Willebois, 1965, 7). De Willebois sê: „De Ik-zelf-dialoog verkommert naar mate de Ik-Gij-verhouding beperkt blijft tot een inperatiewe en/of zichzelf tegensprekende monoloog van de kant van de ouders. Daarmee wordt het kind veroordeeld tot de starre, zich herhalende infantiele bestaansvorm (De Willebois, 1965, 61) Talle opvoedingsfoute kan lei tot 'n powere ek-self-verhouding.

Benewens die omgewingsfaktore, is daar ook die kwessie van oorerwing en aanleg, bv. swak vitaliteit, met gevolglike lewensangs en onwil om die ouerlike beskerming te verlaat (Wijngaarden, 1963, 98/99). Of die persoon kan vaskleef aan die gedagte van eie onwaardigheid. Die kind en jongmense se eie verantwoordelikheid in die uitbou van hierdie verhoudings, speel ook 'n rol.

'n Onoorsigtelike aantal faktore kan lei tot verwarring en verstarring op hierdie verhoudingsvlak. Elke ouer het die taak om die kind tot selfstandige volwassenheid te lei: tot 'n mens met 'n gesonde en bevredigende Ek-self-verhoudingsvlak. 
III.1.3. Die gevolge van die Ek-self-verwarring is verreikend en ingrypend van aard. Die gesonde persoon het 'n gesonde kernbeeld van homself. Hy weet wartoe hy in staat is, en waartoe nie. Daarvolgens bou hy 'n bevredigende lewe uit. Hoe onstabieler die eie identiteit is, hoe meer wisseling kom in die selfbeeld voor. Dikwels sien 'n mens dit by die alkoholis: 'n oordrewe negatiewe selfbeeld en 'n oordrewe positiewe selfbeeld, wat mekaar op 'n onrealistiese wyse vervang.

Die vermindering van selfinsig is 'n onbewuste poging om die kwynende selfvertroue te stimuleer (Smith, 1961, 193). Benewens die aktiewe vorms van selfvervreemding, is daar die passiewe vorm wat uitloop op verveling. Luypen het gesê: „Verveling is de affectieve reactie van het $\mathrm{Ik}$ op het onbevredigd blijven van een of meer strevingen" (De Willebois, 1965, 176). Dit is opvallend dat verveling direkte verband hou met die oormatige drink van drank.

Vervreemd van homself en van ander leef baie alkoholiste in 'n vereensaming, wat hulle nie anders weet te deurbreek as deur drank nie: die roes van skynbevrediging.

Dit is seker genoeg om aan te toon dat selfbegrip en selfaanvaarding die basis verskaf, waarvandaan die persoon kan voortgaan tot nuwe vlakke van aanpassing (Rogers, 1942, 40).

III.1.4. Benewens wat reeds onder 11.4. genoem is, wil ek nog die volgende, wat vir die bearbeiding van belang is, hier noem:

a) Daar is geen ander manier om onsself beter te leer ken, as om alleen te wees met God nie (Heynen, 19). Aanvanklik gaan dit nie maklik met die godsdiensbeoefening nie, maar onder die genadeverkondiging en voortdurende aanmoediging kom daar godsdiensontplooiing. Dit is absoluut noodsaaklik dat die alkoholis aanvaar dat hy 'n ellendige sondaar is - maar 'n geredde sondaar (Rice, 1957, 446/447). In die lig van God se teenwoordigheid, sien ons ons sonde en gebreke en in die lig van sy vergewende liefde kry die sondaar moed tot eerlike selfinsig. Kennis van jou ellende lei tot jou verlossing (Heidelbergse Kategismus, vraag 2).

b) Glaser verklaar: „Morals, standards, values, or right and wrong behavior are all intimately related to the fulfillment of our need for selfworth" (Clinebell, 1966, 238). Daarom moet die alkoholis, sover die vertrouensband dit toelaat, gekonfronteer word met sy foute. Dit moet altyd in liefde gedoen word. Wat die persoonlike gesprek aanbetref, is dit noodsaaklik dat die vertrouensband gedurigdeur opgehou en uitgebou moet word. Clinebell sê: „Both insight - oriented and supportive counseling methods depend on a strong, empathic pastor-parishioner relationship" (Clinebell, $1966,140)$.

c) Die bieggesprek (katarsis) het ook hier waarde. Emosionele reiniging vind plaas as die persoon hom uitpraat, en dit herhaaldelik weer kan doen. Die pastor moet begrypend kan luister en moet die persoonlike betekenis van wat gesê word, kan snap en evalueer. Klink noem dit ,the most difficult of all arts" (Klink, 1965, 20).

d) Psigiatriese of sielkundige behandeling van die alkoholis, 
kan vir die pastor dikwels, veral wat hierdie bearbeidingsvlak aanbetref, besondere waarde hê.

\section{III.2. Die ek-jy-verhoudingsvlak}

III.2.1. Die mens staan in talle verhoudings met sy medemense. Tournier sê: „Niemand ontkomt aan de behoefte van gemeenschap" (Tournier, 56). Clinebell noem die volgende „basic heart-hungers":

Sekuriteit: Die innerlike gevoel van veiligheid en stabiliteit, wat 'n persoon in 'n verhouding waarin hy aanvaar word, kry.

Diens: Die gee van jouself vir ander.

Agting: Die bewus wees dat jy erken, gerespekteer en waardeer word.

Liefde: Die ervaring dat ander vir jou omgee. Hy noem die liefde die mees basiese en onvervangbare behoefte van enige mens (Clinebell, 1966, 147).

Die Bybel praat baie duidelik: die gee van liefde en die ontvang van liefde is die sluitstene van die menslike bestaan. Alleen in 'n doeltreffende sosiale omgewing kan die mens werklik lewe. Daarom het die Here Eva aan Adam gegee as 'n hulp. Gewoonlik voel dié alkoholis bedreig deur die persone waarmee hy in verband staan (Swanepoel, 1964, 125).

III.2.2. Die oorsake van die versteuring op die vlak is weer eens veelvuldig. Daar is vae, algemene oorsake. In sy boek: „De vereenzaming van de moderne mens", toon Couwenburg aan dat talle faktore soos die versaakliking en instrumentalisering van menslike verhoudings, vervreemding van God, verval van die kerklike gemeenskapslewe, die buitensporige indiwidualistiese mededinging, die gejaagde lewenstempo, die enorme tegniese ontwikkeling, veranderings van die gesinstruktuur, bydra tot die moderne verskynsel van onvermoë tot liefde (Couwenburg, 1959, 31-60). Rolls May het ons tyd die "schizoid-age - our age of unrelatedness" genoem (Clinebell, 1966, 109).

Daar is ook egter spesifieke oorsake. Reeds is genoem dat verwarring in die Ek-self-verhoudingsvlak ook hier sy nadelige gevolge het (en anders om!). Die vereensamingsproses teenoor ander by die alkoholis kan dikwels teruggevoer word tot sy opvoeding. Oorstrenge opvoeding, suksesaanbidding deur ouers, moralisme (Clinebell, 1956, 232) verwenning en oorbeskerming deur die moeder, en nog vele ander opvoedingsfoute, lei tot vervreemding. Die eerste onderrig in die sosiale lewe kry die kind tuis. Volgens Erik Erikson en ander lê die allervroegste optrede van die moeder teenoor die baba, reeds die fondament vir die kind se ontwikkeling van vertroue of wantroue in sy omgewing.

Juis die onvermoë om werklik sosiaal te verkeer, laat die persoon dikwels drink. Met die ontspannenheid wat drank verskaf, kan hy sosiaal verkeer en skynbevrediging kry.

III.2.3. Die individu wat nie bevredigende verhoudings met an- 
der het nie, ervaar voortdurende frustrasie. Dit gee aanleiding tot 'n gevoel van mislukking en angs. Hy voel bedreig. Daardeur word die selfbegrip genadeloos afgetakel. ' $n$ Verdedigende gedragspatroon word aangeneem en verdedigingsmeganismes soos aggressie, onsosiabiliteit, sieklike mededinging, verwerping van ander, rasionalisasie, projeksie, outisme, wrok, haat, grootdoenerigheid ens. mag na vore kom (Kretch, 1963, 119/125). Dit is reaktiewe pogings tot angstige selfbeveiliging. Teenoor liefdevolle gebondenheid staan angsvolle vervreemding (Wijngaarden, 1963, 116). Dit rig ontsettend skade aan. As 'n mens maar na een verhouding, die huwelik, kyk, kan 'n mens 'n idee vorm van die angswekkende dieptes wat daar in die versteuring van die verhoudingsvlak, lê.

III.2.4. Die volgende pastorale aspekte is hier van belang:

a) Die bewussyn van die liefde van Christus, gee liefde in die hart (1 Joh. $3: 14$ ). Carl Jung het gesê: „The individual who is not anchored to God can offer no resistance on his own resources to the physical and moral blandishments of the world" (Hanna, 1967, 161). Godsdiens bied die sekuriteit waarin die persoon die „waagstuk" tot sosiale verbondenheid kan aangaan.

b) Die aanpassing op die ek-jy-vlak is 'n onbegonne taak as daar nie op die ek-self-vlak verdieping plaasvind nie.

c) Groepsbearbeiding speel hier 'n groot rol. In die beskermende groep kan die alkoholis sy kommunikasie-angs oorwin. Die alkoholis kan hier werklik leer om sosiale verantwoordelikhede te aanvaar.

d) Opname in die gemeenskapslewe van die kerk is noodsaaklik. Hierdie gemeenskapslewe bereik sy hoogtepunt in diens. Dan kan die alkoholis werklik homself wees (Tournier, 170).

e) Diens teenoor jou naaste lei altyd tot bevryding (Gal. $5: 13$ ) ook in die ek-jy-verhouding.

\section{III.3. Die Ek-dit-verhoudingsvlak}

Dit is een van die kenmerke van die alkoholis: 'n kortsluiting tussen die ek en die omgewing, die dit-deel van die lewe. Die alkoholis het beheer oor sy omgewing verloor.

III.3.1. Die Ek-dit-verhouding is nie van minder belang, omdat dit met dinge te doen het nie. Die predikant wat die „dinge" maar buite rekening laat, sal tot sy spyt dikwels uitvind dat al sy arbeid aan skerwe spat. Baie van die angs van die alkoholis kan na hierdie verhoudingsvlak teruggevoer word; so ook die verwoestende skuldgevoelens.

III.3.2. Die oorsake is weer eens menigvuldig: sommige vaag en algemeen, ander weer skerp persoonlik. Selfvervreemding, vervreemding van ander lei tot vervreemding van die wêreld. Alkohol skep 'n onwerklike koningskompleks (Clinebell, 1956, 50), maar bring mettertyd nog groter verwarring en onmag. Die werklike en gewaande ontoereikendheid is verantwoordelik vir baie ontwrigting. 
Dit lei tot ontduiking van die krisissituasie, en skep daardeur nog groter krisissituasies, met groter ontoereikendheid. Hier kan genoem word dat die opvoeding, aldus McCord en McCord e.a., ook hier 'n groot rol speel.

III.3.3. Die gevolge is verreikend: 'n sneeubal wat altyd groter en groter word. Die ondraagbare angs. Carver noem alkoholisme 'n vlug uit die werklikheid (Esser, 1960, 123). In 'n antropologiese studie van 56 primitiewe samelewings is gevind dat daar 'n direkte verband bestaan tussen angs i.v.m. broodwinning (geleentheid, gebrek, ens.) en drankmisbruik (William, 1967, 277).

In sy kliniese ontleding van die alkoholis het Swanepoel gevind dat angs, depressie, fantasie en immobilisasie by die alkoholis voorkom. Eise wat die omgewing aan hom stel, is bo sy vermoë (Swanepoel, 1964, 125). Die verwarring is die ek-dit-verhoudingsvlak. Die weiering of onvermoë om verantwoordelikheid te aanvaar, het baie gevolge in al die ander verhoudingsvlakke. Alles wat Job moes deurworstel, bring hy ook in verband met God. Daardeur word sy lyde nog dieper. Sy jeukende swere, sy stoflike verlies en die tragedie in sy familie, is nie die ergste nie - die ergste is dat hy God nie meer begryp en nie meer weet wat hy van Hom moet dink nie. Daardeur tuimel hy in die sinloosheid en doelloosheid van alles in.

III.3.4. Die lewe van die alkoholis is dikwels ,obstacle centered" of „problem centered” (Smith, 1961, 201). Daarom sal die pastor wel deeglik rekening moet hou met die probleme op hierdie verhoudingsvlak.

a) Die godsdienstige opvoeding gee aan die alkoholis 'n nuwe verhouding teenoor die wêreld van die dinge. Dit help die mens uit die verlorenheid teenoor die wêreld tot verantwoordelikheid teenoor die wêreld (Bohne, 1960, 58). Ook hiervoor is die inskakeling by die kerklike gemeenskap en godsdientsige aktiwiteite.

b) Ook hier het die groepsbearbeiding besondere waarde. In die groep word nuwe realistiese gedragspatrone en nuwe waardes makliker aangeleer.

\section{III.4. Die Ek-God-verhoudingsvlak}

III.4.1. Ek beskou dit as die belangrikste verhoudingsvlak. Dit is soos Abbing sê: „Als de blijde overtuigde lewensgerichtheid op God taant, omdat God tot een raadsel en vraagteken wordt, verbleken alle kleuren in het leven en daalt er een grijze mist, die verlamt" (Abbing, 1962, 39). Alhoewel die rol van godsdiens al dikwels onder die soeklig geplaas is, is daar tog ' $n$ mate van huiwerige versigtigheid wat die godsdienstige benadering aanbetref, te bespeur (Allport, 1967, 4/76). Tog is reeds van verskeie kante op die noodsaaklikheid van die godsdienstige benadering van die alkoholis gewys. Die medikus, dr. Esser sê: De beste therapie van de alcoholist is zijn religieuze gevoel te versterken, want het religieuze leven is de beste profylaxe tegen de verslaving" (Esser, 1960, 126).

III.4.2. Die legio faktore wat die $\mathrm{Ek}-$ God-verhoudingsvlak in 
die verwarring bring, kan weer eens onderskei word in algemene en besondere faktore. Ons beleef vandag 'n duidelike wegbeweeg van die godsdiens af. Maar daar is talle persoonlike faktore. Opvoeding is weer een van die belangrikste. Deur 'n koue, formele godsdienspatroon van die ouers, moet die godsdienstigheid van die kinders verloop in 'n toevallige godsdienstigheid, sonder dieper betekenis. Mussen het dit raak gesê: „The vast majority of adolescents espouse the religion of their parents and most maintain attitudes and opinions similiar to their parents" (Mussen, 1963, 95).

III.4.3. Die gevolge van die vervreemding op die vlak, is eweneens legio. Waar daar op die ander vlakke vervreemding intree, gebeur hier nog iets diepers: drank neem die plek van God in (Clinebell, 1956, 145). Alkohol word die beginsel waarvolgens die hele lewenspatroon ingerig word. Clinebell onderskei drie soorte angs by die alkoholis (Clinebell, 1966, 237):

Neurotiese angs: 'n Ontvlugtingsmiddel om die onaanvaarbare gevoelens en dryfvere onbewus te hou.

Historiese angs: Die mens het onseker geword; so baie dinge is onbeheerbaar. Dit gee aanleiding tot die bekende toekomsvrees. Eksistensiële angs: Dit is die gevolg van die ineenstorting van die mens se wêreldbeeld. Vrae rondom hierdie angs is: Wie is ek? Waar hoort ek? Waarin glo ek? - allerlei vrae wat verband hou met die sinsverlies, die onsin en absurditeit van die lewe (De Willebois, 1965, 99).

Deurdat die mens sy God verloor, word hy 'n onbeduidende spikkeltjie, sinloos in die gevaarlike skepping. Godsdiensloosheid voed neurose (Hanna, 1967, 31). Vervreemding op hierdie lewensvlak is die sleutel tot die gebrokenheid van die mens (Wijngaarden, 1963, 39). Dit tref alle lewensvlakke.

III.4.4. In die herstel van die Ek-God-verhouding is die pastor nie die bewerker van die heil nie, maar die instrument. Die mens op soek na sin en sekerheid, die mens verlore tussen toekoms en verlede, die mens wat smag na diepgaande interpersoonlike gemeenskap, kan dit slegs werklik diep, bevredigend vind as hy hom tot God keer (De Willebois, 1965, 99/118/127).

Clinebell het 'n hele aantal alkoholiste (lede van Alkoholiste Anoniem) ondervra. Hy het gevind dat daar 'n direkte verband tussen die lengte van die nugterheid en die relatiewe regsinnigheid van hul godsdiens was. ,The author divided his interviewees in term of their God - concepts, ranging from atheïst - agnostic to orthodox. Those in the atheist - agnostic category, though several had associated with A.A. for considerable periods of time, had - with one exception - relative unstable and brief periods of sobriety" (Clinebell, 1956, 134).

Daarom moet die gesprek, die groepsbyeenkomste, die kerklike gemeenskapslewe, die aktivering van die alkoholis, die nuwe vriendskapsbetrekkinge daarop ingestel wees om hierdie verhouding te verinnig. Aansporing tot die gebedslewe, huisgodsdiens, gereelde 
bywoning van kerklike aktiwiteite en lees van godsdienstige lektuur, het sy plek.

Daar moet gewaak word om godsdiens in die alkoholis se keel af te druk. Ons moet slegs lei — die alkoholis moet self aanvaar en doen. Voortdurend moet godsdiens as dankbaarheid voorgehou word. Die onvolwasse opvatting van godsdiens mag bv. daartoe aanleiding gee dat hy godsdiens wil gebruik, of soos 'n alkoholis dit raak uitgedruk het: met Gods wil ,bargain”. Omdat godsdiens vir hom iets magies inhou, verwag hy dat God al die struikelblokke sal verwyder. In die vereensaamde toestand is die mens geneig om na iets te soek wat vry maak van verantwoordelikheid. As hy dit van godsdiens verwag, is sy godsdienstige behoefte eerder 'n belemmering van goeie aanpassing, as 'n bevordering (Jellinek, $1965,29)$. Godsdiens beteken kinderlike oorgawe aan God, en dankbare aanvaarding van ons eie verantwoordelikhede.

Slot: In bogenoemde is die lyne rofweg deurgetrek. Die pastorale bediening van die alkoholis en die familie van die alkoholis stel sy eie, en lewer sy probleme. Maar dit is en bly 'n heerlike werk, omdat dit gedoen word in die Naam van die Koning van die kerk.

A. P. C. Duvenage.

Referaat gelewer tydens studiedag Suid-Afrikaanse Nasionale Raad insake alkoholisme. Algemene jaarvergadering 1969.

\section{VERWYSINGS}

Abbing, Dr. P. J. Roscam: Zielzorg (Boekencentrum, 's Gravenhage, 1962). Alkoholiste Anoniem: Program vir die Rehabilitasie van alkoholiste en hoe die broederskap werk (Potch. Herald Edms. Bpk.).

Alport, Gordon W.: Becoming - basic consideration for a psychology of personality (Yale University Press, New Haven, 1967).

Bavinck, Dr. H.: Gereformeerde Dogmatiek (Deel III, J. H. Kok, Kampen, '1929).

Bohne, Gerhard: Aufgabe und Weg der Erziehung in der Verantwortung vor Gott (Zweiter Band der „Grundlagen der Erziehung", Furche-Verlag, Hamburg, 1960).

Clinebell, Howard, J.: Understanding and Counseling the Alcoholic through Religion and Psychology (Abingdon Press, New York, 1956).

Clinebell, Howard J.: Mental Health through Christian Community (Abingdon Press, New York, 1965).

Clinebell, Howard J.: Basic types of Pastoral Counseling (Abingdon Press, Nashville, 1966).

De Klerk, W. J.: Die pastor en figuurlike selfmoord (Referaat gelewer tydens pastorale simposium te Potchefstroom, 1965, afgerol).

De Willebois, Jhr. Dr. A. E. M. van der Does: Vervreemding en verslaving psigopatologische aspecten van het hedendaagse alcoholisme (Dekker en Van de Vegt, Utrecht-Nijmegen, 1965).

Esser, P. H.: Alcoholism (J. H. Kok, Kampen, 1960).

Hanna, Charles, B.: The face of the deep - the religious ideas of C. J. Jung (Westminister Press, Philadelphia, 1967).

Hoff, Ebbe Curtis: Comprehensive Rehabilitation Program for Alcoholics, in: „Archives of Environmental Health", Vol. 7, Okt. 1963.

Honig, Dr. A. G.: Handboek van de Gereformeerde Dogmatiek (J. H. Kok, Kampen, 1938).

Jellinek, E. M.: The disease concept of alcoholism. (College and University Press, New Haven, 1968). 
Jones, Howard: Alcohol Addiction: A Psycho-social approach to abnormal drinking (Tavistock Publication, 1963).

Keller, John E.: Ministering to alcoholics (Augsburg Publishing House, Minneapolis, 1966).

Klink: Depth perspectives in pastoral work (Prentice Hall, Inc., Englewood Cliffs, 1965).

Krech, David en Crutchfield, Richard S. en Ballachey Egerton L.: Individual in Society (McGraw - Hill Book Co., Inc. New York, 1962).

Kruger, J.: Die pastor en die alkoholis (Referaat gelewer op pastorale simposium te Potchefstroom, 1965, afgerol).

Kuypers, Dr. A.: Inleiding in de Zielkunde (J. H. Kok, Kampen, 1963).

Manis, Melvin: Social interaction and the self-concept in „Journal of Abnormal and Social Psychology", Nov. 1955, 51/3.

McCord, W. en McCord, J.: Orignis of Álcoholism (Tavistock Publications Ltd., London, 1960).

McKenzie, John G.: Guilt: Its meaning and significance (Abingdon Press, New York, 1962).

Oates, Wayne I.: Alcohol in and out of the church (Broadman Press, Nasheville, Tennessee, 1966).

Pop, F. J.: Bijbelse woorden en hun geheim (Deel I, Boekencentrum, 's Graven. hage, 1957).

Rice, Otis R:: Pastoral Counseling of Ibriates, in: „Quarterly Journal of studies in Alcohol", 1957.

Rogers, Carl R.: Counseling and Psychotherapy (Houghton Mifflin Company, Cambridge, 1942).

Smith, Henry Clay: Personality adjustment (McGraw-Hill Book Co., New York, 1961).

Swanepoel, J. C.: Persoonlikheidsontleding van 'n groep alkoholiste met behulp van die T.A.T.-toets (Voorgele ter vervulling van 'n deel van die vereistes vir die graad Magister Artium in die Departement Sielkunde, Fakulteit Lettere en Wysbegeerte, Universiteit van Pretoria, Feb. 1964).

Tournier, Dr. Powl: De weg uit de eenzaamheid (N.V. Gebr. Zomer en Keuning Uitgeversmaatschappij, Wageningen, ongedateerd).

William, Echhardt: Alcoholic Values and Alcoholic Anonymous in "Quarterly Journal of Studies on Alcohol", Junie 1967, Vol. 28, nr. 2).

Wijngaarden, Prof. Dr. H. R.: Hoofdproblemen der volwassenheid (Erven Bijleveld, Utrecht, 1963). 